\section{Heliconia wagneriana Petersen is a Short-day Plant}

Richard A. Criley ${ }^{1}$

Department of Horticulture, University of Hawaii, Honolulu, HI 96822-2279

William S. Sakai ${ }^{1}$

College of Agriculture, University of Hawaii, Hilo, HI 96720-4091

Additional index words. photoperiod, rainbow heliconia

Abstract. Seasonal flowering behavior of Heliconia wagneriana Petersen was found to be caused by short daylengths (SD) using artificial short days (8 to 9 hours) and long days as daylength extension or night break lighting with incandescent lamps. The natural time for flower initiation was estimated to be mid- to late October (11 hours 40 minutes to 11 hours 20 minutes) in Hawaii, and 120 to 150 days were required from the onset of inductive SD to inflorescence emergence. The results may be used to manipulate flower availability for flower markets. plants of $H$. wagneriana 'Rainbow' were grown on raised benches outdoors in 20 - $\mathrm{L}$ metal cans containing $(\mathrm{v} / \mathrm{v}) 8$ volcanic cinders : 1 ProMix (Premier Peat Moss, Red Hill, Pa.). Plants were grown under natural daylengths until given long days (LD), consisting of the natural daylength extended by $0.9 \mathrm{~W} \cdot \mathrm{m}^{-2}$ from incandescent lights from 6:00 to 10:00 PM. Long days were provided to six groups of six plants beginning 1 Oct. 1987 through 1 Apr. 1988. A seventh set of plants was maintained under natural daylengths (ND). Plants from this experiment were recycled into a follow-up experiment in which 15 plants were given ND through the rest of the year and 15 were given 10 -h daylengths beginning 1 Sept. 1988 , by pulling black plastic over them from 6:00 PM until 10:00 AM. Flowering was noted Jan. through May 1989.

The experiment at the Manoa campus was conducted during late Summer 1989 through
Marketers of heliconia cut flowers are faced with seasonal gluts and periods of no production. A popular species with good keeping quality, $H$. wagneriana Petersen produces heavily in the late winter-early spring months in Hawaii, peaking during March and April. In early reports on heliconias as nectar sources for hummingbirds (Stiles, 1975) and as insectrich sites (Seifert, 1975), its narrow blooming season was noted, together with the fact that flowering occurs in the dry season (late December through late April, with a peak in February and March) in the Costa Rican rainforest. On the other hand, Daniels and Stiles (1979) indicate a peak of flowering at the end of the dry season in April and May. Growers would like to be able to market it for early winter holidays as well as for later spring use. Inspection of grower shipping records (Fig. 1) confirms its narrow blooming period in Hawaii.

Our experiments were conducted independently to determine the photoperiod responsiveness of $H$. wagneriana and to extend the production period for the cut flower. The sites were at the Hilo Agricultural Farm Laboratory of the Univ. of Hawaii at Hilo and the Manoa campus of the Univ. of Hawaii in Honolulu.

\section{Materials and Methods}

The experiments in Hilo were conducted during the late Summer 1987 through Spring 1988 and Fall-Winter 1988-89, using plants established from single rhizome pieces propagated in June 1985. The flowering cycle of these plants in 1986-87 (Fig. 2) was similar to that of the Oahu grower (Fig. 1). Established

Received for publication 15 July 1996 . Accepted for publication 3 Apr. 1997. Journal Series No. 4237 of the Hawaii Institute of Tropical Agriculture and Human Resources. The cost of publishing this paper was defrayed in part by the payment of page charges. Under postal regulations, this paper therefore must be hereby marked advertisement solely to indicate this fact.

'Professor.

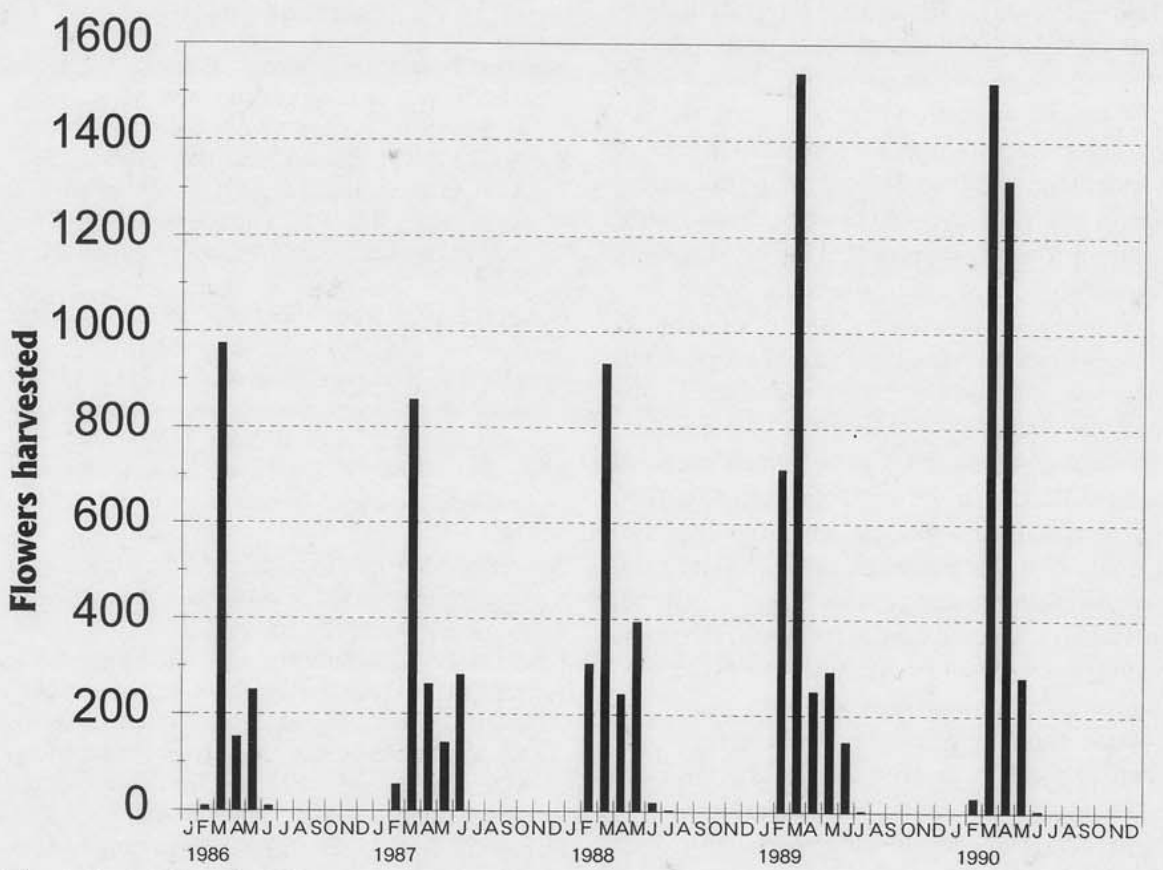

Fig. 1. Seasonality of Heliconia wagneriana cut flowers during 1986-90 as recorded by sales records of a commercial grower in windward Oahu, Hawaii.

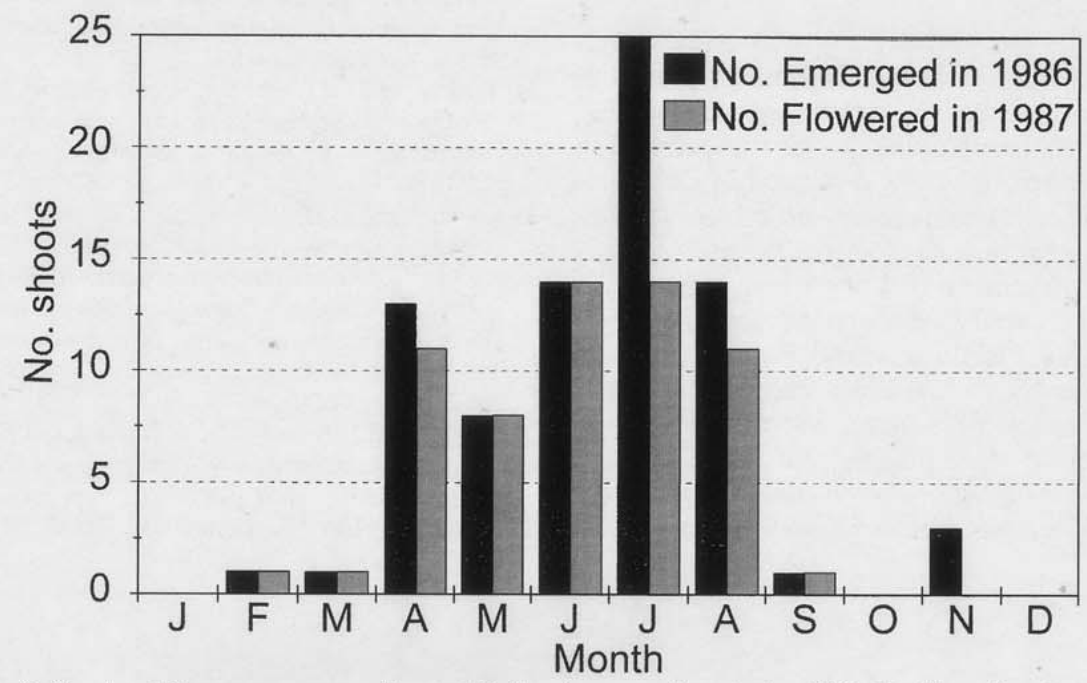

Fig. 2. Shoot and flower emergence of potted Heliconia wagneriana during 1986-87. Flowering shoots of 1987 were those that emerged in 1986. 
Table 1. Effect of 16-h photoperiods (LD) on flowering of Heliconia wagneriana. Data recorded Apr. 1988.

\begin{tabular}{lc}
\hline Start of LD & Effect on flowering \\
\hline 1 Oct. 1987 & No flowering \\
1 Nov. 1987 & No flowering \\
1 Dec. 1987 & No flowering \\
1 Jan. 1988 & Flowering $^{z}$ \\
1 Feb. 1988 & Flowering $^{z}$ \\
1 Mar. 1988 & Flowering \\
Natural daylengths only & Flowering \\
\hline
\end{tabular}

${ }^{\mathrm{z}}$ All six pots flowered; no flower count taken.

spring 1990. Short day (SD), LD, and ND were provided to two $60-\mathrm{cm}$ tubs (each treatment) containing established $H$. wagneriana 'Turbo' plants bearing 13 to 22 shoots. The medium volume was $120 \mathrm{~L}$ of equal parts volcanic cinders and composted redwood plus controlled release fertilizer $(18 \mathrm{~N}-3.8 \mathrm{P}-9.9 \mathrm{~K}$; Osmocote; Grace-Sierra Co., Milpitas, Calif.), dolomite, and treble superphosphate at rates of 4,6 , and $2 \mathrm{~kg} \cdot \mathrm{m}^{-3}$, respectively. Unfurled leaves were counted on each tagged shoot at the beginning of the experiment and on 15 May 1990, when the experiment was concluded. The plants were grown outdoors in full sunlight. Thirteen weeks of SD (8 to $9 \mathrm{~h}$ duration) were provided by moving the plants on a large cart into a $23^{\circ} \mathrm{C}$ dark chamber from 29 Aug. through 30 Nov. 1989. Long days were provided by a night break between 10:00 $\mathrm{PM}$ and 2:00 AM from two incandescent floodlamps $\left(25 \mathrm{~W} \cdot \mathrm{m}^{-2}\right)$, also beginning 29 Aug. 1989 but continuing through Mar. 1990. Natural daylengths ranged from 13.5 to $10.9 \mathrm{~h}$. Inflorescence emergence was defined as emergence of all bracts from the enclosing pseudostem. Plants in a nearby field were observed as well.

\section{Results and Discussion}

In the Hilo experiment, LD prevented flower initiation when provided in October, November, and December, but flowers were still produced on plants given LD starting in January through April (Table 1). Plants provided SD from 1 Sept. began blooming a

Table 2. Number of plants of Heliconia wagneriana of 15 that flowered for the first time each week when grown under ND or SD from 1 Sept. 1988 through May 1989.

\begin{tabular}{|c|c|c|c|c|c|c|c|c|c|c|c|c|}
\hline \multirow{3}{*}{ Photoperiod } & \multicolumn{12}{|c|}{ Month/day } \\
\hline & \multirow{2}{*}{$\frac{\text { Feb. }}{22}$} & & \multicolumn{4}{|c|}{ Mar. } & \multicolumn{4}{|c|}{ Apr. } & \multicolumn{2}{|c|}{ May } \\
\hline & & $\overline{1}$ & 8 & 15 & 22 & 29 & 5 & 12 & 19 & 26 & 3 & 10 \\
\hline ND & 0 & 0 & 0 & 0 & 1 & 0 & 1 & 3 & 2 & 1 & 1 & 0 \\
\hline SD & 1 & 2 & 2 & 2 & 0 & 0 & 0 & 0 & 0 & 0 & 0 & 0 \\
\hline
\end{tabular}

Table 3. Initiation and development of inflorescences in Heliconia wagneriana 'Turbo' grown under three photoperiods beginning 29 Aug. 1989.

\begin{tabular}{llcccr}
\hline \hline Photoperiod & $\begin{array}{c}\text { Date of first } \\
\text { inflorescence }\end{array}$ & $\begin{array}{c}\text { No. } \\
\text { inflor. }\end{array}$ & $\begin{array}{c}\text { Mean weeks } \\
\text { from start }\end{array}$ & $\begin{array}{c}\text { Mean no. } \\
\text { bracts }\end{array}$ & $\begin{array}{c}\text { No. leaves } \\
\text { below inflor. }\end{array}$ \\
\hline SD & 23 Dec. 1989 & 7 & 17.3 & 5.9 & 5.6 \\
ND & 25 Feb. 1990 & 2 & 27.0 & 6.0 & 5.5 \\
LD & --- & ---- & - & - \\
\hline
\end{tabular}

month before plants given ND (Table 2).

Many shoots failed to develop an infloreseence on plants in tubs at Manoa, perhaps because of the dehydration stress of wind upon exposed plants. Nonetheless, six of seven inflorescences were produced within $10 \mathrm{~d}$ of each other on SD plants (Table 3), and emergence of the two inflorescences borne by ND plants coincided with the emergence of flowers in field plantings. The LD plants did not flower during the period under observation. The ND inflorescences emerged $\approx 9$ weeks later than those of the SD plants. This would place the natural stimulus for initiation in midto late-October if $120 \mathrm{~d}$ is required from initiation to emergence. Dissection of pseudostems of field-grown $H$. wagneriana under natural photoperiods had shown inflorescences of 2to 7-cm length in December (Criley and Lekawatana, 1990). Five to six leaves subtended the inflorescences; plants averaged 2.2 leaves at the start of the photoperiod treatments, somewhat fewer than for another SD species, H. stricta (Criley and Kawabata, 1985).

The experiments demonstrate that flowering of $H$. wagneriana can be advanced by imposing SD during the LD of summer or delayed by lighting during the inductive SD of fall. In this respect, $H$. wagneriana behaves like a typical SD plant. We suggest that flower initiation occurs in October and initiation or development can be prevented by LD. The Manoa data indicated that a minimum of 120 days is required from initiation until the inflorescence is visible, but in Hilo, which is cooler, $150 \mathrm{~d}$ may be required. Commercial growers will harvest at a stage about two to three weeks after emergence of the inflorescence, when three or four bracts have reflexed. This accounts for three weeks of the Hilo-Manoa difference.

\section{Literature Cited}

Criley, R.A. and O. Kawabata. 1985. Evidence for a short-day flowering response in Heliconia stricta 'Dwarf Jamaican'. HortScience 21:506-507.

Criley, R.A. and S. Lekawatana. 1990. Managing seasonality of flowering in heliconia, p. 167172. In: The Hawaii tropical cut flower industry conference. Univ. of Hawaii HITAHR Res. Ext. Ser. 124.

Daniels, G.S. and F.G. Stiles. 1979. The Heliconia taxa of Costa Rica. Keys and descriptions. Brenesia 15(Suppl):1-149.

Seifert, R.P. 1975. Clumps of Heliconia inflorescences as ecological islands. Ecology 56:14161422.

Stiles, F.G. 1975. Ecology, flowering phenology, and hummingbird pollination of some Costa Rican Heliconia species. Ecology 56:285-301. 